\title{
Heavy metals in muscle tissue of healthy crocodiles from the Kruger National Park, South Africa
}

\author{
Marinus du Preez ${ }^{1}$, Danny Govender ${ }^{2,3}$ and Hindrik Bouwman ${ }^{1 *}$ \\ ${ }^{1}$ Research Unit: Environmental Sciences and Management, North-West University, Private Bag X6001, \\ Potchefstroom, 2520, South Africa, \\ ${ }^{2}$ Veterinary Wildlife Services, South African National Parks, Private Bag X402, Skukuza, 1350, South Africa and \\ ${ }^{3}$ Department of Paraclinical Sciences, University of Pretoria, Private Bag X04, Onderstepoort, 0110, South \\ Africa
}

*Correspondence: E-mail: henk.bouwman@nwu.ac.za

\section{Introduction}

Mass mortality of Nile crocodile (Crocodylus niloticus) occurred in the Olifants River of the Kruger National Park (KNP) in 2008 from pansteatitis, a condition in which body fat becomes yellow and inflamed. Much research has been carried out, but the cause(s) of the outbreak in the KNP remains unknown (Ashton, 2010; Ferreira \& Pienaar, 2011; Woodborne et al., 2012; Bouwman et al., 2014). Anthropogenic factors such as heavy metal pollution have been suggested as a potential cause (e.g. Bouwman et al., 2014). We found only three studies from Africa on heavy metals in wild crocodiles (Table 1). The aim of this study was to assess the concentrations of heavy metals and metalloids in wild and apparently healthy crocodiles in the KNP.

\section{Materials and methods}

We participated in a wider South African National Parks (SANParks) programme to assess the health of wild crocodiles in the KNP, with appropriate ethical clearance. Six major rivers run through the KNP (Smith, Van Zyl \& Bouwman, 2000), each draining large catchments with different anthropogenic and natural sources of minerals and contaminants (Fig. 1a). In August 2010, we collected muscle samples from the tails of twelve crocodiles (CS1-CS12) from rivers representing seven catchments (Sabie, Olifants, Crocodile, Levuvhu, Shingwedzi, Nwaswitsontso and Letaba rivers). More about these crocodiles can be found in Osthoff et al. (2014). 
Table 1 Results (mg/kg dry mass) of heavy metal analyses of Nile crocodiles from various rivers in the Kruger National Park and comparable data from elsewhere in the world

\begin{tabular}{|c|c|c|c|c|c|c|c|c|c|c|c|c|c|c|c|c|c|c|c|c|c|c|c|c|c|}
\hline Species & Tisue & Year & Sample & Location & $\mathrm{Al}$ & $\mathrm{Cu}$ & $\mathrm{Hg}$ & $\mathrm{Pb}$ & cr & $\mathrm{Ni}$ & $c_{0}$ & $\mathrm{~cd}$ & $\mathrm{zn}$ & $\mathrm{Se}$ & As & $\mathrm{Ti}$ & $\mathrm{Mn}$ & $\mathrm{Fe}$ & $\mathrm{v}$ & $\mathrm{Pt}$ & $\mathrm{Au}$ & $\mathrm{Ag}$ & U & $\mathrm{Sn}$ & Reference \\
\hline $\begin{array}{l}\text { Nile } \\
\text { crocodile } \\
\text { (CS1) }\end{array}$ & Muscle & 2010 & Dry & $\begin{array}{l}\text { Crocodile } \\
\quad \text { River, (KNP) } \\
\text { South Affrica }\end{array}$ & 19 & 0.31 & 1.5 & 0.15 & 0.09 & 0.024 & 0.0061 & 0.005 & 1.4 & 0.9 & 0.041 & 0.13 & 0.25 & 115 & 0.26 & 0.0094 & 0.084 & 0.17 & 0.025 & 0.038 & This study \\
\hline $\begin{array}{l}\text { Nile } \\
\text { crocodile } \\
\text { (CS2) }\end{array}$ & Muscle & 2010 & Dry & $\begin{array}{l}\text { Crocodile } \\
\text { River, (KNP) } \\
\text { South Africa }\end{array}$ & 16 & 0.042 & 2.8 & 0.1 & 0.08 & 0.027 & 0.005 & 0.0079 & 0.92 & 1.2 & 0.042 & 0.13 & 0.14 & 301 & 0.13 & 0.0078 & 0.026 & 0.073 & 0.01 & 0.022 & This study \\
\hline $\begin{array}{l}\text { Nile } \\
\text { crocodile } \\
\text { (CS3) }\end{array}$ & Muscle & 2010 & Dry & $\begin{array}{l}\text { Olifants } \\
\text { River. (KNP) } \\
\text { South Africa }\end{array}$ & 15 & 0.7 & 0.86 & 0.0089 & 0.094 & 0.027 & 0.0013 & 0.0033 & 1.4 & 0.46 & 0.033 & 0.12 & 0.17 & 295 & 0.054 & 0.0079 & 0.017 & 0.037 & 0.012 & 0.01 & This study \\
\hline $\begin{array}{l}\text { Nile } \\
\text { crocodile } \\
\text { (CS4) }\end{array}$ & Muscle & 2010 & Dry & $\begin{array}{l}\text { Olifants } \\
\text { River, (KNP) } \\
\text { South Africa }\end{array}$ & 19 & 0.67 & 0.27 & 0.0082 & 0.14 & 0.04 & 0.01 & 0.016 & 5.8 & 0.69 & 0.049 & 0.3 & 0.25 & 335 & 0.081 & 0.0063 & 0.019 & 0.022 & 0.014 & 0.007 & This study \\
\hline $\begin{array}{l}\text { Nile } \\
\text { crocodile } \\
\text { (CS5) }\end{array}$ & Muscle & 2010 & Dry & $\begin{array}{l}\text { Shingwedzi } \\
\text { River,(INP) } \\
\text { South Africa }\end{array}$ & 33 & 0.95 & 1.5 & 0.074 & 0.11 & 0.035 & 0.01 & 0.0041 & 1.9 & 1.62 & 0.061 & 0.0035 & 0.45 & 150 & 0.53 & 0.0056 & 0.0068 & 0.015 & 0.13 & 0.0098 & This study \\
\hline $\begin{array}{l}\text { Nile } \\
\text { crocodile } \\
\text { (CS6) }\end{array}$ & Muscle & 2010 & Dry & $\begin{array}{l}\text { Levuvuu } \\
\text { River, (KNP) } \\
\text { South Africa }\end{array}$ & 8.8 & 0.059 & 0.22 & 0.02 & 0.096 & 0.02 & 0.0007 & 0.0037 & 0.27 & 0.42 & 0.039 & 0.098 & 0.14 & 77 & 0.25 & 0.006 & 0.004 & 0.005 & 0.012 & 0.0037 & This study \\
\hline $\begin{array}{l}\text { Nile } \\
\text { crocodile } \\
\text { (CS7) }\end{array}$ & Muscle & 2010 & Dry & $\begin{array}{l}\text { Levuvhu } \\
\text { River, (KNP) } \\
\text { South Africa }\end{array}$ & 1.7 & 0.014 & 0.022 & 0.006 & 0.052 & 0.012 & 0.0004 & $<0.00007$ & 0.29 & 0.04 & 0.029 & 0.036 & 0.032 & 18 & 0.052 & 0.00045 & 0.0004 & 0.0005 & 0.0053 & $<0.00002$ & This study \\
\hline $\begin{array}{l}\text { Nile } \\
\text { crocodile } \\
\text { (Css) }\end{array}$ & Muscle & 2010 & Dry & $\begin{array}{r}\text { Nwaswitsontso } \\
\text { River, (KNP) } \\
\text { South Africa }\end{array}$ & 22 & 1.5 & 0.14 & 0.088 & 0.06 & 0.033 & 0.0002 & 0.0016 & 1.8 & 0.57 & 0.037 & 0.25 & 0.35 & 305 & 0.57 & 0.0048 & 0.0063 & 0.01 & 0.0068 & 0.0064 & This study \\
\hline $\begin{array}{l}\text { Nile } \\
\text { crocodile } \\
\text { (cs9) }\end{array}$ & Muscle & 2010 & Dry & $\begin{array}{l}\text { Nwawitsontso } \\
\text { River, (KNP) } \\
\text { South Africa }\end{array}$ & 31 & 2.8 & 0.21 & 0.13 & 0.091 & 0.028 & 0.0023 & 0.0026 & 3.7 & 0.99 & 0.06 & 0.21 & 0.33 & 301 & 0.18 & 0.0079 & 0.0078 & 0.02 & 0.055 & 0.0086 & This study \\
\hline $\begin{array}{l}\text { Nile } \\
\text { crocodile } \\
\text { (CS10) }\end{array}$ & Muscle & 2010 & Dry & $\begin{array}{l}\text { Letaba } \\
\text { River, (KNP) } \\
\text { South Africa }\end{array}$ & 28 & 1.3 & 1.4 & 0.048 & 0.069 & 0.035 & 0.0031 & 0.0071 & 2.1 & 1.3 & 0.043 & 0.0018 & 0.42 & 175 & 0.54 & 0.0039 & 0.005 & 0.01 & 0.0083 & 0.0067 & This study \\
\hline $\begin{array}{l}\text { Nile } \\
\text { crocodile } \\
\text { (CS11) }\end{array}$ & Muscle & 2010 & Dry & $\begin{array}{l}\text { Letaba } \\
\text { River, (KNP) } \\
\text { South Africa }\end{array}$ & 26 & 1.4 & 2.4 & 0.43 & 0.074 & 0.027 & 0.0006 & 0.0094 & 4.7 & 1.7 & 0.11 & 0.0021 & 0.19 & 523 & 0.39 & 0.0033 & 0.019 & 0.0073 & 0.033 & 0.0054 & This study \\
\hline $\begin{array}{l}\text { Nile } \\
\text { crocodile } \\
\text { (CS12) }\end{array}$ & Muscle & 2010 & Dry & $\begin{array}{l}\text { Sabie } \\
\text { River, (KNP) } \\
\text { South Africa }\end{array}$ & 16 & 0.27 & 0.22 & 0.063 & 0.075 & 0.023 & 0.0014 & 0.0022 & 2.1 & 0.49 & 0.038 & 0.12 & 0.26 & 261 & 0.26 & 0.0057 & 0.016 & 0.013 & 0.014 & 0.006 & This study \\
\hline $\begin{array}{l}\text { Nile } \\
\text { crocodile }\end{array}$ & Muscle & 2000 & Wet & $\begin{array}{l}\text { Crocodile } \\
\text { farm, South } \\
\text { Africa }\end{array}$ & 7 & & & & & & & & 11 & & & & & 3 & & & & & & & $\begin{array}{l}\text { Hoffinan, } \\
\quad \text { Pisher \& } \\
\text { Sales, 2000: }\end{array}$ \\
\hline $\begin{array}{l}\text { Nile } \\
\text { crocodile }\end{array}$ & Muscle & 2000 & Dry & $\begin{array}{l}\text { Olifants } \\
\text { River, (KNP) } \\
\text { South Africa }\end{array}$ & 147.2 & 10.5 & & 20.3 & 9.8 & 10.3 & & & 39.4 & & & & 0.1 & 399.6 & & & & & & & $\begin{array}{l}\text { Swanepool, } \\
\text { Boomker \& } \\
\text { Kriek, 2000; }\end{array}$ \\
\hline $\begin{array}{l}\text { Nile } \\
\text { crocodile }\end{array}$ & Muscle & 2000 & Dry & $\begin{array}{l}\text { Sabie } \\
\text { River, (KNP) } \\
\text { South Africa }\end{array}$ & 73.5 & 12.6 & & 0 & 18.4 & 9.1 & & & 44.7 & & & & 0.1 & 615.4 & & & & & & & $\begin{array}{l}\text { Swanepooel, } \\
\text { Boomker \& } \\
\text { Kriek, 2000: }\end{array}$ \\
\hline $\begin{array}{l}\text { Nile } \\
\text { crocodile }\end{array}$ & Muscle & 2000 & Dry & $\begin{array}{l}\text { Silvervis } \\
\text { Dam, (KNP) } \\
\text { South Africa }\end{array}$ & 376.8 & 7.9 & & 3.7 & 90.5 & 24.9 & & & 109.7 & & & & 17.8 & 156 & & & & & & & $\begin{array}{l}\text { Swanepoel, Boomker } \\
\text { \& Kriek, 2000; }\end{array}$ \\
\hline $\begin{array}{l}\text { Nile } \\
\text { crocodilie }\end{array}$ & Liver & 2004 & Wet & $\begin{array}{l}\text { Kafue River, } \\
\text { Zambia }\end{array}$ & & 5.7 & 3.5 & 8.7 & & & 0.02 & 0.04 & 18 & 1.8 & 0.008 & & 1.4 & & & & & & & & Almli et al.. 2005; \\
\hline $\begin{array}{l}\text { Nile } \\
\text { crocodilie }\end{array}$ & Liver & 2004 & Wet & $\begin{array}{l}\text { Luangwa } \\
\text { River, } \\
\text { Zambia }\end{array}$ & & 4 & 3.7 & 3.3 & & & 0.05 & 0.04 & 31 & 2.3 & 0.049 & & 1.1 & & & & & & & & Almli et al., 2005; \\
\hline Alligator & Muscle & 2011 & Dry & $\begin{array}{l}\text { Louisiana, } \\
\text { USA }\end{array}$ & & 8.8 & & & & & & & 52.8 & & & & & 41.9 & & & & & & & Guillory et al., 2011; \\
\hline $\begin{array}{l}\text { Chinese } \\
\text { alligator }\end{array}$ & Muscle & 2006 & Dry & $\begin{array}{l}\text { Anhui } \\
\text { Province, } \\
\text { China }\end{array}$ & & 6.4 & 0.193 & 0.73 & 0.155 & & & 0.155 & 120.97 & & 0.306 & & 2.68 & 67 & & & & & & & Xu et al., 2006; \\
\hline
\end{tabular}




\begin{tabular}{|c|c|c|c|c|c|c|c|c|c|c|c|c|c|c|c|c|c|c|c|c|c|c|c|c|c|}
\hline Species & Tisue & Year & Sample & Location & $\mathrm{Al}$ & $\mathrm{Cu}$ & $\mathrm{Hg}$ & $\mathrm{Pb}$ & Cr & $\mathrm{Ni}$ & $c_{0}$ & $\mathrm{~cd}$ & $\mathrm{zn}$ & $\mathrm{Se}$ & As & $\mathrm{Ti}$ & $\mathrm{Mn}$ & $\mathrm{Fe}$ & $\mathrm{v}$ & $\mathrm{Pt}$ & $\mathrm{Au}$ & $\mathrm{Ag}$ & u & $\mathrm{Sn}_{\mathrm{n}}$ & Reference \\
\hline $\begin{array}{l}\begin{array}{l}\text { Bstuarine } \\
\text { crocodile }\end{array} \\
\end{array}$ & Muscle & 2011 & Dry & $\begin{array}{c}\text { Alligator } \\
\text { Rivers } \\
\text { Region, } \\
\text { Australia }\end{array}$ & 89.9 & 1.14 & & 0.308 & 0.413 & 0.507 & & & 81.4 & 0.993 & & 6.22 & 0.706 & $88.7 \mathrm{c}$ & & & & & & & $\begin{array}{l}\text { Jeffree, Markich \& } \\
\text { Twining, 2011; }\end{array}$ \\
\hline Alligator & Muscle & 1985 & Dry & $\begin{array}{l}\text { Lake Rodman, } \\
\text { Florida USA }\end{array}$ & & 0.28 & 0.51 & 0.07 & 0.05 & & & 0.02 & 19 & & & & & 7.42 & & & & & & & $\begin{array}{l}\text { Delany. Bell \& } \\
\text { Sundlof, 1988: }\end{array}$ \\
\hline Alligator & Muscle & 1985 & Dry & $\begin{array}{l}\text { Lake Hancock, } \\
\text { Florida USA }\end{array}$ & & 0.34 & 0.1 & 0.1 & 0.05 & & & 0.01 & 25.5 & & & & & 8.45 & & & & & & & $\begin{array}{l}\text { Delany, Bell \& } \\
\text { Sundlof. 1988: }\end{array}$ \\
\hline Alligator & Muscle & 1985 & Dry & $\begin{array}{l}\text { Lake Orange, } \\
\text { Florida USA }\end{array}$ & & 0.39 & 0.37 & 0.04 & 0.05 & & & 0.06 & 27.88 & & & & & 17.7 & & & & & & & $\begin{array}{l}\text { Delany, Bell \& } \\
\text { Sundlof. 1988: }\end{array}$ \\
\hline Alligator & Muscle & 1985 & Dry & $\begin{array}{l}\text { Lake Newnans. } \\
\text { Florida USA }\end{array}$ & & 0.41 & 0.27 & 0.12 & 0.05 & & & 0.02 & 36 & & & & & 15.38 & & & & & & & $\begin{array}{l}\text { Delany, Bell \& } \\
\text { Sundlof. 1988; }\end{array}$ \\
\hline Alligator & Muscle & 1985 & Dry & $\begin{array}{l}\text { Lake Apopka, } \\
\text { Florida USA }\end{array}$ & & 0.4 & 0.11 & 0.07 & 0.03 & & & 0.03 & 14.2 & & & & & 4.56 & & & & & & & $\begin{array}{l}\text { Delany, Bell \& } \\
\text { Sundlof, 1988: }\end{array}$ \\
\hline Alligator & Muscle & 1985 & Dry & $\begin{array}{l}\text { Lake George, } \\
\text { Florida USA }\end{array}$ & & 6.03 & 0.04 & 0.09 & 0.06 & & & 0.03 & 2.17 & & & & & 22.76 & & & & & & & $\begin{array}{l}\text { Delany, Bell \& } \\
\text { Sundlof, 1988: }\end{array}$ \\
\hline Alligator & Liver & 2014 & Dry & $\begin{array}{l}\text { Lake Apopka, } \\
\text { Florida USA }\end{array}$ & 13 & 25.2 & 1.76 & 2 & 0.261 & & 0.0285 & 0.0869 & 84.5 & 5.46 & 0.111 & 0.0022 & 2.38 & 1770 & 0.672 & & & & & 0.0661 & Horai et al., 2014 \\
\hline Alligator & Liver & 2014 & Dry & $\begin{array}{l}\text { Lake Woodruff, } \\
\text { Florida USA }\end{array}$ & 18.6 & 26.7 & 7.77 & 0.349 & 0.385 & & 0.0334 & 0.0955 & 86.5 & 11.2 & 0.122 & 0.00221 & 2.97 & 3690 & 0.385 & & & & & 0.0609 & Horai et al.. 2014 \\
\hline
\end{tabular}


(a)

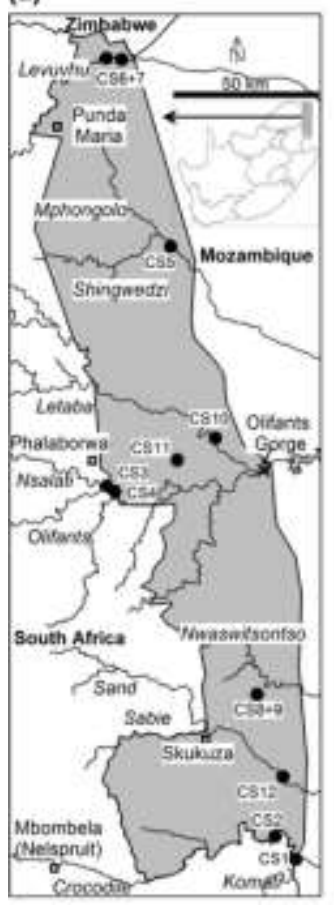

(b)

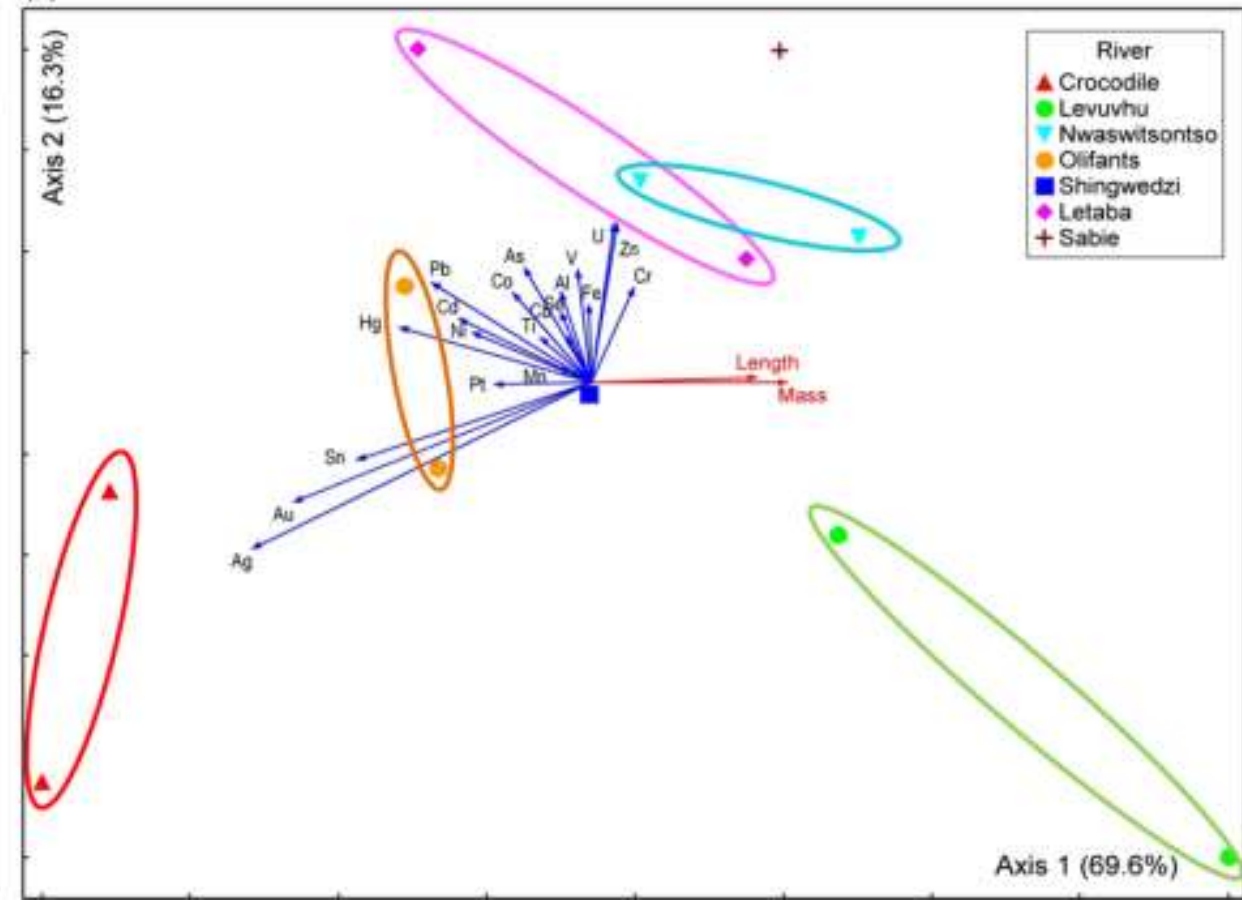

Figure 1. (a) Crocodile sampling sites within the borders of the Kruger National Park. (b) Nonmetric multidimensional scaling of relativized concentrations of twenty metals and metalloids in Nile crocodile muscle tissue. Ellipses indicate different rivers.

Muscle samples were stored at $-20^{\circ} \mathrm{C}$. Twenty metals and metalloids were analysed at North-West University using the revised EPA 3050B method with ICP-AES, using $2 \mathrm{~g}$ of dried sample in a $50 \mathrm{ml}$ mixture of $\mathrm{HNO}_{3}, \mathrm{H}_{2} \mathrm{O}_{2}, \mathrm{HCl}$ and deionized water. We only used multivariate analyses due to small sample numbers. Nonmetric multidimensional scaling (NMS) was performed on data relativized per sample as compositional fingerprint, with crocodile mass and length used as descriptive variables.

\section{Results and Discussion}

CS2 from the Crocodile River had the highest concentration of $\mathrm{Hg}$; CS4 from the Olifants River had the highest concentrations of $\mathrm{Cr}, \mathrm{Cd}, \mathrm{Zn}$ and Ti; CS1 from the Crocodile River had the highest concentrations of Pt, $\mathrm{Au}$ and $\mathrm{Ag}$; and CS12 from the Sabie River had the highest $\mathrm{Cu}$ concentration (Table 1). The higher concentrations are also reflected in Fig. $1 \mathrm{~b}$, where the most of the respective longer vectors associated with the Olifants and Crocodile rivers. Gold and silver are often mined together and have a strong association with Crocodile River crocodiles, while $\mathrm{Pb}, \mathrm{Cd}, \mathrm{Ni}, \mathrm{Hg}$ and $\mathrm{Mn}$ were distinctly associated with Olifants River crocodiles. The compositional fingerprints from the Letaba and Shingwedzi rivers were dominated by $\mathrm{U}, \mathrm{Zn}$ and $\mathrm{Cr}$. (Table 1), and they ordinated away from the other rivers (Fig. 1b). Despite the few samples, the distinction in compositional fingerprints based on metals and metalloids may be due to mining and other anthropogenic activities in the catchments of the different rivers. The Olifants River catchment has activities such as coal, platinum, chrome, vanadium, iron and copper, and water quality seems to be under severe pressure (Ashton, 2010). The Crocodile River catchment has large irrigation and forestry schemes, as well as wood and paper mills. However, very little is known about pollution in 
this river. Very little is also known about the pollution status of the Sabie, Letaba, Nwaswitssontso and Shingwedzi catchments, but an association of the first four with $\mathrm{U}, \mathrm{Cr}$ and $\mathrm{Zn}$ is of concern. Most of the Nwatswistsontso and Shingwedzi catchments are protected and within the KNP borders. The concentrations therefore most likely reflect geological background. Luvuvhu River crocodiles had the lowest heavy metal concentrations (especially Fe), probably due to the lack of any major mining or industry in the region. The interpretation of the pollution differences above should be cautioned by the fact that crocodiles are mobile - however, the large distances between the rivers probably reduce the likelihood of relocation of individuals between the major catchments.

One would expect that if metals and metalloids played a role in the deaths of the crocodiles, the pollution would be systematic of the catchment; therefore much higher in the Olifants River and therefore also in its crocodiles. By comparing concentrations within the KNP and with data from elsewhere (Table 1), it can be deduced that this was not the case - the concentrations from the Olifants River crocodiles were within the same orders of magnitude than samples from the KNP or elsewhere with no pansteatitis. Provisionally, we conclude that the metals and metalloids we measured is an unlikely primary cause of pansteatitis.

Longer and heavier crocodiles had lower concentrations of metals in their muscle tissue than smaller crocodiles (Fig 1b). This can be the result of dilution due to growth, depuration with age and/or a larger component of terrestrial prey that may have lower concentrations of metals than aquatic prey (Cott, 1961; Hutton, 1987).

The crocodiles we sampled in 2010 all had relatively lower concentrations than those sampled in 2000 (Table 1). The samples from 2000 had some of the highest concentrations measured anywhere in the world, so it seems that contamination levels have declined markedly for most metals and metalloids over a period of 10 years. However, $\mathrm{Hg}$ had the highest concentrations in crocodile muscle tissue sampled in 2010 from anywhere in the world and is a matter of concern.

\section{Conclusions}

The crocodile samples by and large had distinctive and catchment-specific heavy metal fingerprints. These fingerprints are likely a combination of anthropogenic contamination, underlying geology, the mobility of crocodiles and a greater dependence of larger crocodiles on terrestrial herbivores rather than fish. The concentrations seem to have declined with time, but relatively high concentrations in the Olifants and Crocodile rivers and mercury in general are of concern. Overall, the heavy metal concentrations in crocodile muscle from the Olifants River are in the same orders of magnitude compared with other KNP crocodiles or crocodiles elsewhere in the world. Heavy metals therefore are unlikely to have been a primary cause of pansteatitis.

\section{References}

Almli, B., Mwase, M., Sivertsen, T., Musonda, M.M. \& Flaoyen, A. (2005) Hepatic and renal concentrations of 10 trace elements in crocodiles (Crocodylus niloticus) in the Kafue and Luangwa rivers in Zambia. Sci. Total Environ. 337,75-82. 
Ashton, P.J. (2010) The demise of the Nile crocodile (Crocodylusniloticus) as a keystone species for aquatic ecosystem conservation in South Africa: the case of the Olifants River. Mar. Freshwater Ecol. 20, 489-493.

Bouwman, H., Booyens, P., Govender, D., Pienaar, D. \& Polder, A. (2014) Chlorinated, brominated, and fluorinated organic pollutants in Nile crocodile eggs from the Kruger National Park, South Africa. Ecotoxicol. Environ. Safety 104, 393-402.

Cott, H.B. (1961) Scientific results of an enquiry into the ecologyand economic status of the Nile crocodile (Crocodylus niloticus) in Uganda and Northern Rhodesia. Trans. R. Soc. Lond. 29, 211-356.

Delany, M.F., Bell, J.U. \& Sundlof, S.F. (1988) Concentration of contaminants in muscle of the American alligator in Florida. J. Wildl. Dis. 24,62-66.

Ferreira, S.M. \& Pienaar, D. (2011) Degradation of the crocodile population in the Olifants River Gorge of Kruger National Park, South Africa. Aquatic Conserv. Marine Fresh. Ecol. 21, 155-164.

Guillory, G., Hardaway, C.J., Merchant, M.E. \& Sneddon, J. (2011) Determination of selected metals in Alligator (Alligator mississippiensis) tissue by inductively coupled plasms-optical emissions spectrometry. Instrument. Sci. Technol. 39, 368-373.

Hoffman, L.C., Fisher, P.P. \& Sales, J. (2000) Carcass and meat characteristics of the Nile crocodile (Crocodylus niloticus). J. Sci. Food. Agricult. 80, 390-396.

Horai, S., Itai, T., Noguchi, T., Yasuda, Y., Adachi, H., Hyobu, Y., Riyadi, A.S., Boggs, A.S.P., Lowers, R., Guillette, L.J. \& Tanabe, S. (2014) Concentrations of trace elements in American alligators (Alligator mississippiensis) from Florida, USA. Chemosphere 108, 159-167.

Hutton, M.J. (1987) Growth and feeding ecology of the Nile Crocodile Crocodylus niloticus Ngezi, Zimbabwe. J. Anim. Ecol. 56,25-38.

Jeffree, R.A., Markich, S.J. \& Twining, J.R. (2011) Element concentrations in the flesh and osteoderms of estuarine crocodiles (Crocodylus porosus) from the Alligator Rivers Region, northern Australia: biotic and geographic effects. Arch. Environ. Contam. Toxicol. 40, 236-245.

Osthoff, G., Hugo, A., Govender, D., Huchzermeyer, K.D.A. \& Bouwman, H. (2014) Comparison of the lipid composition of three adipose tissue types of male and female wild Nile crocodiles (Crocodylus niloticus). J. Hepatol. Malignancies 48, 525-531.

Smith, H.J., Van Zyl, A.J.Bouwman, H. (2000) An action plan for water quality research and technology transfer in the rivers flowing through the Kruger National Park. WRC Report No 988/1/00.

Swanepoel, D., Boomker, J. \& Kriek, N.P.J. (2000) Selected chemical parameters in the blood and metals in the organs of the Nile crocodile, Crocodylus niloticus, in the Kruger National Park. Onderstepoort J. Vet. Res. 67, 141-148.

Woodborne, S., Huchzermeyer, K.D.A., Govender, D., Pienaar, D.J., Hall, G., Myburgh, J.G., Deacon, A.R., Venter, J. \& Lubcker, N.(2012) Ecosystem change and the Olifants River crocodile mass mortality events. Ecosphere 3, 17.

Xu, Q.H., Fang, S.G., Wang, Z.W. \& Wang, Z.P. (2006) Heavy metal distribution in tissues and eggs of Chinese alligator (Alligator sinensis). Arch. Environ. Contam. Toxicol. 50, 580-586. 